Marquette University

e-Publications@Marquette

Theology Faculty Research and Publications

Theology, Department of

$1-1-2014$

Where is Abel thy Brother? Reframing the Theological Horizons for Catholic Theories of Just War

Philip J. Rossi

Marquette University, philip.rossi@marquette.edu

Accepted version. Journal of Catholic Social Thought, Vol. 11, No. 1 (Winter 2014): 229-240. DOI. (C) 2014 Philosophy Documentation Center. Used with permission. 


\title{
Where is Abel thy Brother? Reframing the Theological Horizons for Catholic Theories of Just War
}

\author{
Philip J. Rossi \\ Department of Theology, Marquette University \\ Milwaukee, WI
}

This essay starts from a presupposition that there is need for rethinking the theological framework within which the Catholic Church has articulated its understanding of the principles and the application of the theory of "just war" in the social teaching it has proposed since the conclusion of World War II. ${ }^{1}$ While it may also be the case that the articulation of just war principles within other Christian theological traditions needs a similar re-framing, my primary concern is with the place it has occupied within Catholic moral and social teaching for the last sixty years. I will first provide a brief overview of the main considerations why such rethinking seems needed, but the main thrust of my argument is to outline the direction that such rethinking could take. I will also propose that an important outcome of such rethinking 
would be to provide a clear focus on the establishment of peace as the proper finality of a theologically informed just war theory.

\section{Is (Catholic) Just War Teaching Still Theological?}

The fundamental question posed in this section is: In what way can a theory of "just war"-at least as it is currently articulated in the Catholic tradition-any longer be considered "theological" or even "religious"? Though just war theory has long been a topic within discussions of Christian theological ethics, it no longer seems fully evident that a necessary condition for its intelligibility and/or its persuasive power is provided by its location or function within a theological or religious context.

In order to show this, let me trace key portions of the historical trajectories along which just war theory has traveled within the Catholic tradition up to the start of the twenty first-century. Some conceptual elements of just war theory antedate Christian thinkers such as Augustine and Aquinas who made major contributions to its formulation and development. Just as they did with many other key concepts and theories from the intellectual milieu of their times, they each shaped those elements into congruence with the overarching theological concerns guiding their work. I hope that it is not too simplistic to say that they each deeply embedded the concepts and reasoning we now associate with classic expressions of just war thinking into a powerful theological context, even when those concepts did not themselves arise from an explicitly theological provenance. As James Turner Johnson has observed "just war doctrine in its classic form is not solely a product of Christian moral thought but derives also from two distinct secular traditions: the chivalric code and the legal idea of jus gentium."2

It is thus important to note, moreover, that even as Aquinas later appropriated elements of Augustine's treatment of war into his own thinking, he embedded them into a theological context that, even as it was indebted to Augustine, was nonetheless different from that of Augustine. For instance, Augustine takes the injunction to love one's 
neighbor to provide theological ground for the possibility of legitimating war:

...there are two distinct beginning points or emphases in Augustine's view of the necessity of war. One is the practical political perception that social life demands that order be preserved, even if at the cost of violence. The other is the Christian religious conviction that love controls the entire moral life, even when violent coercion is morally demanded to serve the neighbor, punish the enemy, and protect the common good. ${ }^{3}$

While Aquinas, like Augustine, will "approach the justification of violence from the standpoint of the needs of the political community and its citizens," his account shifts the main weight of its theological focus away from what Lisa Cahill terms Augustine's "tensive dialectic between caritas and concupiscence." 4 Of greater concern for Aquinas are considerations of right order and justice shaped on an Aristotelian model of political community, that within "the reality of an encompassing realm of divine activity and providence" has "its own coherency and positive raison d'être." 5 This shift in thinking about what justifies civil authority's use of violence and, in particular, its prosecution of war to discharge its responsibility for the protection of order and the common good, was not simply a result of changes that took place in the intellectual context during the many centuries that separated Aquinas from Augustine. Not unlike the circumstances that surround more recent discussions of just war theory, it was also a response to concrete changes in the material conditions of the political and social order that had taken place in the West since Augustine's day. ${ }^{6}$

The Aristotelian elements that Aquinas brings to bear upon questions of war, however, do not completely displace the Augustinian elements, with the result that "in the teaching of Thomas Aquinas two quite different notions of a just war can co-exist without being explicitly contrasted."7 In the subsequent development of just war thinking within Catholic theology, the Aristotelian side, particularly as systematized under the symbol of "natural law," usually played the more prominent role. Catholic theologians of later centuries, such as Francisco Suárez and, most notably, Francisco de Vitoria, play an 
important role in the refinement of just war thinking along lines based on natural law and the equally venerable notion of jus gentium (the law of nations). ${ }^{8}$ Vitoria's contribution, which includes "the first clear and complete formulation of what has come to be conceived as the classic requirements of just war $^{\prime \prime 9}$ arises, not surprisingly, in the context of the need to address a new set of circumstances, specifically, the Spanish conquest of the native peoples of the Americas. That Vitoria could offer an extensive and trenchant "just war" criticism of the Spanish policies-a criticism that did lead to at least some reformsupports the claim made by James Johnson that "by the end of the Middle Ages just war tradition had solidified into a general cultural consensus on the justification and proper limits of the use of force. ${ }^{\prime 10}$

Even though Augustinian elements have not generally taken the lead role in shaping the more recent trajectory of Catholic just war thinking, they did appear prominently in other Christian theologians' reflection upon war and civil order. The thinking of the Reformers appropriates Augustine's emphasis on the central role of neighbor love and this theme recurs, in a slightly different key, in the work of Reinhold Niebuhr and Paul Ramsey, two Protestant theologians who were major participants in discussions of just war in the middle years of the twentieth century. Lisa Cahill notes that:

In the Augustinian tradition, the legitimation of violence is grounded in a killing-as-love paradox, and the extension of love to cover the "loved" victim is taken up by the Reformers. Reinhold Niebuhr and Paul Ramsey also build violence out of love, though more narrowly as service to the vicitmized but innocent neighbor. ${ }^{11}$

The Augustinian focus on love of neighbor places great weight on the proper inner dispositions and right intention of the one who, however reluctantly, must employ the violence justified by that love. Its fundamental measure thus applies first to intentions and dispositions, rather than to external conduct. Perhaps because of this-or perhaps because its articulation and defense rests, both for Augustine and its later proponents, on more explicitly Scriptural and theological grounds than is immediately evident in a just war theory framed in terms of natural law-this focus on love of neighbor has had far less impact on the articulation of just war theory as it gained stature as part of the 
secular discourse of modern international law. While more the more general dynamics of "secularization" may have a role in the "detheologizing" of just war thinking, the principal phenomenon that has attracted my attention is the way in which this "de-theologizing" has happened even among the practitioners of theological discourse. A significant consequence of the trajectories along which just war thinking has traveled is that it now stands in what seems to be the unique position of being characteristically identified with the teachings of the Roman Catholic church ${ }^{12}$-and thus as paradigmatic of a particular form of Christian moral discourse-yet also sufficiently part of the general discourse of public policy and even of international law, that one need not be an adherent of any religious position, let alone a Catholic or Christian one, to recognize coherence and suasive power in its principles. ${ }^{13}$

If I have correctly traced these historical trajectories of just war thinking, then it seems to be the case that it now regularly functions in public discussion-even when invoked by Catholic theologians and prelates-as a form of argument that, despite its historically long association with theological discourse and reasoning, neither stands nor falls on any particular theological principles or religious presuppositions. By one measure, this may be counted as gain-an instance, perhaps, of the capacity of human beings to grasp, through the exercise of reason, the truth of principles rooted in what Catholic theology has termed natural law. By another measure, however, a just war theory that stands apart from any recognizably theological context is puzzling in light of the dynamism of its origin and development, particularly if one remembers that the fundamental trajectory of the theological projects of Augustine and Aquinas enabled them to read all human activity-and indeed all of reality-in terms of its theological intelligibility. So what I propose to explore in the next section are a number of possibilities for providing just war theory, at least in its Catholic articulation, with a renewed, or perhaps even a new, context of theological intelligibility. 


\section{Toward a Renewed Theological Framework: Solidarity, Mutuality, and an Eschatological/Cosmopolitan Horizon of Peace}

In this section, I will propose two elements that I consider necessary for articulating a renewed Catholic theological horizon for just war thinking. The first element consists in the articulation of a theological anthropology of human mutuality and solidarity-i.e., an account of our human condition for which our relation to the divine serves as horizon of intelligibility for the dynamics of our relation to each other. I will argue that such anthropology can provide the setting for an understanding of our human action as morally efficacious for countering the roots of the deadly violence that seems embedded in the depths of our human relationality. ${ }^{14}$ While this human propensity to violence lends plausibility to Hobbes's stark rendering of our human "state of nature" as bellum omnium contra omnes, an anthropology of human mutuality and solidarity makes it possible to envision how human action-both individual and collective-can bring about social conditions to disempower this propensity to violence. I will then propose, as a second element for this reframed theological horizon, a "eschatological-cosmopolitan" construal of hope as a social commitment to mutuality that provides conditions for empowering morally efficacious practice resistant to the draw to violence. Such hope, I argue, by enabling us to envision "the world as it ought to be $^{\prime \prime 15}$ as a world in which we can render violence powerless by how we act, provides a measure for the efficacy of human action in securing conditions not simply for a diminution of violence but for the establishment of social order to make possible genuine civil and international peace.

The theological horizon from which this anthropology of mutuality and solidarity can take shape is provided, in the first instance, by the narrative of Cain and Abel from the fourth chapter of Genesis. It is of no little significance that the first among the narrated social consequences of the expulsion of Adam and Eve from the garden is the fratricidal violence that engulfs their offspring. This tale certainly suggests something both sobering and profoundly disturbing about how deep down violence goes in our human reality. It confronts us with a chilling reminder of how powerfully the enmity that leads to 
violence can grasp us: Human hostility can rip asunder even the bonds of blood kinship. If the grip of enmity can wrest from us every last shred of fellow feeling for a sibling ("Am I my brother's-or my sister'skeeper?") it is hardly surprising that the socially organized enmity we call war brings us to seek the obliteration of those whose bonds to us have been experienced as less palpable and immediate than Cain's were to Abel.

Yet this primal story of violence also indicates one of the most fundamental coordinates on which our relations to one another as moral beings must take their bearing. I suggest that taking this story as an anthropological point of reference allows us to refocus the theological intelligibility of just war theory though the interpretive lens provided by Cain's self-justifying rhetorical question, "Am I my brother's keeper?" The ironic bite of Cain's question-both for him and for us-lies in the fact that if Cain had recognized that he is, indeed, his brother's keeper, there would have been no violence. It is thus no accident that this stark paradigm of human hostility expressed in the story of Cain and Abel is placed very early in the narrative that, for Jewish and Christian communities of faith, is constitutive of their relation to the One they name God. Within that narrative, the ruptured relation between the siblings Cain and Abel ensues upon the rupturing of the intimate relation their parents, Adam and Eve, once had with the God from whom they received the breath of life. In place of "the LORD God walking in the garden in the cool of the day" (Gen 3:8) in enlivening companionship with humanity, Cain's invitation to his brother, "Let us go out to the field" (Gen 4:8), inverts fraternal companionship into a walk unto death. One does not have to make a long logical or imaginative leap from that bit of narrative irony to the insight that a fundamental condition that makes war possible arises when we put aside any awareness of being "one another's keeper" and steel ourselves against any recognition of our fundamental connection to one another in human solidarity. ${ }^{16}$

The Cain and Abel narrative has not, to my knowledge, functioned as a significant scriptural context for the articulation of just war theory in the documents formative of Catholic discussions of just war theory during the past six decades. ${ }^{17}$ Those documents-and, it seems, much of the just war tradition-seem to take it for granted that, 
with conflict and violence so thoroughly interwoven in the fiber of human interaction, there is little point in reflecting further upon this episode emblematic of our readiness to break the closest of our human connections. At the same time, however, the larger framework of Catholic social teaching has recently given more attention to the fundamental role that "interdependence" and "solidarity" need to play in the institutional ordering of human activity in an increasingly globalized world. ${ }^{18}$ Though specific references to the Cain and Abel story are also sparse in this corner of the discussion, there is a clear thrust to make the interdependent character of human social existence and the mutual recognition of our individual and shared dignity as human persons a central conceptual locus from which action guiding principles-including those that constitute just war theory-are then articulated.

This anthropology of solidarity and mutuality has already had an impact in some areas of the articulation of just war thinking within Catholic teaching. As noted earlier, the development of just war thinking within a theological context involved embedding it within a larger account of the role and responsibility of the sovereign power and its agents to promote the common good of civil society and its members. More recently, Catholic expressions of just war teaching have paid greater attention to the changed circumstances in which modern representative and democratic forms of political order have expanded the scope of citizen responsibility in the public realm in ways that bear upon the role an informed citizenry has in decisions about war and peace. ${ }^{19}$ While reaffirming the ad bellum requirement that the decision to go to war is made by "competent authority," i.e., by the legitimate public authority of the state, the US bishops, in their 1983 letter, The Challenge of Peace, also recognized that it was within the scope of responsibility of individual citizens at least to make their own judgments concerning the fulfillment of the ad bellum criteria, even as decision making power continued to reside in institutions of sovereign governance. Such a judgment could be, in the first instance, the basis on which citizens could exercise a right of "selective conscientious objection" to military service in a particular war. This empowering of the general citizenry goes beyond the responsibility to observe the in bello criteria that just war theory already recognized as residing in the 
hands of individual combatants to refuse to follow orders in violation of the in bello criteria. ${ }^{20}$

In addition, the bishops suggested, in at least two places in The Challenge of Peace, what seem to be a further extension of the scope of a citizen's responsibility for moral judgment with respect to the ad bellum criteria. ${ }^{21}$ This extension provides a basis upon which all citizens, whether or not they are liable to military conscription, may legitimately voice and organize public opposition against decisions engaging their nation in a war they deem unjust. Implicit in the thinking that leads to this expansion of individual citizen responsibility are, not surprisingly, elements of a theological anthropology that is thoroughly social. This anthropology seeks to understand what it is to be human in the light of the human relation to God that encompasses humanity as a thoroughly social reality: A fundamental and inseparable part of understanding what it is to be human is understanding that human persons stand in relation to one another in light of their relationship to God. It is not just that humans are fundamentally social, it is that the social dimension of our humanity is itself part of the relation between humanity and God. How humans stand in relation to one another is fundamentally part of how we are oriented to God.

That such a social anthropology is operative is not all that surprising, since, as I have already noted, it has informed many of the documents of the Catholic social teaching that have issued, both from Rome and from regional conferences of bishops, since the papacy of John XXIII. What has still been little explored, however, are ways in which this social anthropology of mutuality and solidarity thereby limns a horizon of social hope in which peace is envisioned as genuinely possible as the efficacious outcome of intentional human activity. This horizon of social hope enables us to envision the kind of human actions that render powerless our seeming propensity to violence and that secure conditions for the establishment of social order of genuine civil and international peace.

This horizon of social hope is thus what I would like to sketch as the concluding element of this essay. The form in which I will articulate it issues from may appear as an unusual resource for Catholic social 
thought: the cosmopolitan perspective of Immanuel Kant. I propose reading Kant's cosmopolitanism from a framework of Christian eschatology-i.e., from a framework that, even as it affirms divine governance as the ultimate determining agency in the full and final ordering of history, also affirms a constructive role for human agency in the history that reaches its fulfillment in the attainment of "the reign of God." This eschatological framework stands in consonance with the account of efficacious hope for the achievement of the "perpetual peace" that is integral to the constitution of the historical finality of Kant's cosmopolitanism. Kant envisions "cosmopolitanism" as a reorientation of our perspective on the moral efficacy of human action. ${ }^{22}$ It is a vantage point, enabled by the proper exercise of human practical (moral) reason-i.e., by our freedom-from which we empower ourselves and each another to envision the effects of our actions upon the socio-cultural matrix that constitutes the dynamics of history. ${ }^{23}$ It is a view upon our actions that sees them in terms of the social import they have in imparting a trajectory to the course of human history that accords with the moral worth and dignity proper to the freedom we exercise as we stand in mutual relations of respect for each other. Kant images this relationship as "a kingdom of ends" and as "an ethical commonwealth. ${ }^{24}$ One might be able to make a case that, in articulating "cosmopolitanism" as a social re-orientation of our perspective upon the moral efficacy of our freedom, Kant is quite literally seeking to "bring down to earth" at least certain elements of the dynamics of peace that had been envisioned in terms of the "heavenly city" of the Book of Revelation in the Christian New Testament. The re-orientation Kant proposes draws this "other worldly" eschatology closer to the visions of a restored Jerusalem that, in texts such as found in the later chapters of the Book of Isaiah in Hebrew scripture, serves to bring the blessings of a "this worldly" shalom upon humanity.

The connection between eschatology and Kant's cosmopolitanism that I thus put forth is the following: Embedded in the cosmopolitan hope for perpetual peace to which Kant gives the status of a categorical imperative is an eschatological claim that human action makes a genuine difference to the trajectory and outcome of history. At the heart of Kant's account of a cosmopolitan perspective is a principle on which I think that he, Augustine, and 
Aquinas all stand in fundamental agreement: human freedom and action make a real difference to the course of history and to our human destiny as individuals and as a species. In consequence, a cosmopolitan perspective-and, a fortiori, this eschatological perspective on the efficacy of human action-enables us to envision peace not as a mere utopian velleity that remains an unfulfilled wish ever beyond our capacity to effect it, but instead as a concrete outcome that is made increasingly possible by human activities that are effectively ordered to the construction of a world order providing conditions for lasting peace. It allows us to shape our actions with a view to making conditions conducive to peace the actual outcome of concrete activities and policies that are within our human power to put into effect.

Crucial to the connection I am proposing here is that Kant's cosmopolitanism and Christian eschatology, to the extent that they each stress the genuine moral efficacy of human action, thereby offer mutually reinforcing resources for envisioning human responsibility for the establishment of peace. Affirming such eschatological and cosmopolitan possibilities for human freedom to stand effectively against violence and, in so doing, to make a real difference in history has, I believe, relevance for an appropriate theological articulation of just war theory in the twenty-first century. It provides a horizon of hope for the effective power of human freedom that stretches beyond that envisioned by a "realism" that accepts the violence of war as an irremovable and inevitable feature of human life, and for which just war theory provides, at best, an imperfect tool for its occasional moderation. ${ }^{25}$ Within this horizon of a cosmopolitanism and eschatological moral efficacy for human freedom, human beings have the capacity, as agent participants in fashioning the history of the human species, for envisioning peace as a realizable outcome of their action and for enacting peace in the face of the dynamics of war. This is a horizon for envisioning peace not as an "impossible dream" that will come about only in the fullness of a divine eschatological time "beyond" history, but instead as a genuinely "possible dream" that can be brought to closer realization in human time, as a task that that has been entrusted to human hands to bring about. This task is to work to establish forms of social interaction that serve to bring about a peace/shalom that is marked by the presence of a relationality that is

Journal of Catholic Social Thought, Vol 1, No. 1 (Winter 2014): pg. 229-240. DOI. This article is (C Philosophy Documentation Center and permission has been granted for this version to appear in e-Publications@Marquette. Philosophy Documentation Center does not grant permission for this article to be further copied/distributed or hosted elsewhere without the express permission from Philosophy Documentation Center. 
authentically divine and a solidarity that is authentically human. It is within this horizon that an effective order of peace can be affirmed as the fundamental finality of a theologically informed just war theory. ${ }^{26}$

\section{Notes}

1 The principal loci for such teaching in its official form have been in documents such as papal encyclicals, various decrees from Vatican Council II, the synod of bishops, regional conferences of bishops (such as the US bishops' 1983 pastoral letter The Challenge of Peace). A summary of this teaching is found in The Catechism of the Catholic Church \# 2308-2309, 2312-2314.

2 "Morality and Force in Statecraft: Paul Ramsey and the Just War Tradition," in Love and Society: Essays in the Ethics of Paul Ramsey, ed. James Johnson and David Smith (Missoula, Mont.: Scholars Press, 1974), 94.

3 Lisa Sowle Cahill, Love Your Enemies: Discipleship, Pacifism, and Just War Theory (Fortress: Minneapolis 1994) 74.

4 Cahill, 92.

5 Cf. Cahill, 82.

6 A similar dynamic arising from changed material circumstances under which war is waged, as well as in the shape of the international order, plays a role in the way in which contemporary just way thinking has developed in both its theoretical configuration (e.g., the articulation of post-bellum principles) and the scope of its application (e.g., non-state agents, humanitarian intervention, etc.)

7 James Gaffney, "Just War: the Catholic Contribution to International Law," Yamauchi Lectures in Religion (Department of Religious Studies, Loyola University New Orleans: 2003) 9.

8 Gaffney (11-15) sees in Vitoria's discussions a signal contribution to the development of what we have come to term international law.

9 James Turner Johnson, "Morality and Force in Statecraft: Paul Ramsey and the Just War Tradition," 95.

10 James Turner Johnson, "Just War," The Westminster Dictionary of Christian Ethics, ed. James S. Childress and John Macquarrie (Westminster: Philadelphia, 1986) 328. Gaffney also provides a concise overview of Vitoria's role in the emergence of this consensus.

11 Cahill, 94.

12 Cf. Catechism of the Catholic Church 2309, which enunciates the ad bellum principles and 2312-14, which enunciates the in bello principles. It is important to note that, both in church documents in the writings of Catholic scholars, more recent articulations of the moral principles that should govern the exercise of civil and military authority in situations of international conflict move in a direction that indicates 
NOT THE PUBLISHED VERSION; this is the author's final, peer-reviewed manuscript. The published version may be accessed by following the link in the citation at the bottom of the page.

a developing "peace ethics" has started to displace "just war" as a characteristically Catholic position. For perspectives on this development, see the final essays in From Just War to Modern Peace Ethics, ed. Heinz-Gerhard Justenhoven and William A. Barbieri, Jr., Berlin: de Gruyter, 2012: Robert J. Araujo, SJ, "The Holy See as International Person and Sovereign and Participant in International Law," 249-273; Gerard F. Powers, "From an Ethics of War to an Ethics of Peacebuilding," 275-312; and Heinz-Gerhard Justenhoven, "The Peace Ethics of Pope John Paul II," 313-344.

13 A resolution proposed to members of the American Philosophical

Association in 2003 about the war in Iraq provides a striking marker of the extent to which just war theory can be understood as independent of a religious or theological frame of reference. The first sentence of the rationale for the resolution reads: "Both just war theory and international law say that states may resort to war only in selfdefense."

14 See Charles Taylor, A Secular Age, (Cambridge: Harvard University Press, 2007) 656-710 for a useful discussion of the dimensions of violence in the context of the "immanent frame" of meaning that marks the contemporary cultures of secularity.

15 See Susan Neiman, Evil in Modern Thought: An Alternative History of Philosophy (Princeton, Princeton University Press, 2004) 57-84, 314328 , for a trenchant discussion of the moral and metaphysical important of the distinction between the world "as it is" and the world "as it ought to be."

16 An insight conveyed pointedly by Pope Paul VI in his October 1965 speech to the United Nations: "Si vous voulez être frères, laissez tomber les armes de vos mains."

17 The Cain-Abel story does provide a setting for the introductory discussion of the fifth commandment, "Thou shall not kill," in The Catechism of the Catholic Church \#2259. It is not, however, referenced in the discussion of peace and war that begins more than forty paragraphs later in \#2302.

18 See, for instance, Part I, Chapter II (§23-32) of Gaudium et Spes (Pastoral Constitution on the Church in the Modern World) from Vatican Council II.

19 This is just one of the changed material circumstances under which war has been initiated and waged in the 20th and 21st centuries that has had an impact on the structure, scope, and application of just war thinking. These range from the development of weapons technology, an international order in which sovereign nations no longer function as the sole actors, the incorporation of just war principles into various instruments of international law, etc.

Journal of Catholic Social Thought, Vol 1, No. 1 (Winter 2014): pg. 229-240. DOI. This article is (C Philosophy Documentation Center and permission has been granted for this version to appear in e-Publications@Marquette. Philosophy Documentation Center does not grant permission for this article to be further copied/distributed or hosted elsewhere without the express permission from Philosophy Documentation Center. 
20 The bishops pointedly observe that: "to refuse to take such actions [that are unlawful or forbidden in warfare] is not an act of cowardice or treason but one of courage and patriotism (\# 311)."

21 One is \# 324, which urges public officials to be "particularly attentive to the consciences of those who sincerely believe that they may not support warfare in general, a given war, or the exercise of a particular role within the armed forces"; the second, \# 328, quotes, Human Life in Our Day, an earlier pastoral letter: "In our democratic system, the fundamental right of political dissent cannot be denied, nor is rational debate on public policy decisions of government in the light of moral and political principles to be discouraged."

22 See Philip J. Rossi, "Cosmopolitanism: Kant's Social Anthropology of Hope," Kant und die Philosophie in weltbürgerlicher Absicht: Proceedings of the XI International Kant Congress, ed. Stefano Bacin, Alfredo Ferrarin, Claudio La Rocca, Margit Ruffing, (Berlin: Walter de Gruyter, forthcoming 2013).

23 See Philip J. Rossi, "Cosmopolitanism and the Interests of Reason: A Social Framework for Human Action in History," Recht und Frieden in der Philosophie Kants: Akten des X. Internationalen Kant-Kongresses, Vol. 4, ed. Valerio Rohden, et al., (Berlin: Walter de Gruyter, 2008), 65-75.

24 See Philip J. Rossi, The Social Authority of Reason: Kant's Critique, Radical Evil, and the Destiny of Humankind, (Albany: State University of New York Press, 2005), 87-111.

25 Susan Neiman describes such "realism" as "a form of sloth. If you tell yourself that a world without injustice is a childish wish fantasy, you have no obligation to work toward it" (Moral Clarity: A Guide for Grown-up Idealists, Harcourt, Orlando: 2008, p. 145).

26 The increasing attention now being given to the importance of post-bellum considerations suggests that there may be more at work here than just the articulation of an additional set of criteria (parallel to those bearing upon ad bellum and in bello circumstances) for judging the moral adequacy of particular policies or conduct upon the cessation of armed hostilities. At work in the articulation of these post-bellum criteria may very well be an important structural alteration of its theoretical and practical trajectory in which just war theory can be appropriately reoriented to the finality of establishing an order of enduring peace, i.e. toward a an "ethics of just peace."

An earlier version of this essay was presented as part of the 6th Galilee Colloquium, on "The Concept of Peace and War in Religions," Swiss-Israel Philosophical Foundation, Kfar Blum, Israel, in June 2011. I wish to express gratitude to the participants at that conference, to the referees of the Journal of Catholic Social Thought, and to my

Journal of Catholic Social Thought, Vol 1, No. 1 (Winter 2014): pg. 229-240. DOI. This article is (C Philosophy Documentation Center and permission has been granted for this version to appear in e-Publications@Marquette. Philosophy Documentation Center does not grant permission for this article to be further copied/distributed or hosted elsewhere without the express permission from Philosophy Documentation Center. 
NOT THE PUBLISHED VERSION; this is the author's final, peer-reviewed manuscript. The published version may be accessed by following the link in the citation at the bottom of the page.

Marquette colleague, Michael Duffey, for comments that have been helpful in preparing the final text.

Journal of Catholic Social Thought, Vol 1, No. 1 (Winter 2014): pg. 229-240. DOI. This article is (C Philosophy Documentation Center and permission has been granted for this version to appear in e-Publications@Marquette. Philosophy Documentation Center does not grant permission for this article to be further copied/distributed or hosted elsewhere without the express permission from Philosophy Documentation Center. 